suggested higher failure rates of up to 17 pregnancies for every 100 woman years..$^{9} 10$

There are three types of diaphragms: the flat spring type (rigid and less yielding but cheap); the coiled spring type (softer but more difficult to insert); and the arcing spring type that bows on compression. Arcing diaphragms are the most expensive but combine the advantages of the other two. Patients should use the largest comfortable size since the vagina expands on intercourse.

Diaphragms separate spermatozoa from the cervix and prevent the alkaline cervical mucous from neutralising vaginal acid, which is hostile to sperm. ${ }^{11}$ They should be used with spermicide and the Family Planning Association is currently investigating the added efficacy that spermicides confer. Fears that they might have systemic effects on serum lipids or the liver seem unfounded.

Diaphragms offer some protection against primary vaginal infections like chlamydia and gonorrhoea but not against herpes or syphilis. ${ }^{1213}$ Their use is associated with a lowered incidence of pelvic inflammatory disease, infertility, ${ }^{14}$ and cervical neoplasia, ${ }^{15}$ and the spermicide nonoxynol 9 has recently been shown to inactivate the human immunodeficiency virus in vitro. ${ }^{16}$

But diaphragms also have disadvantages apart from their high failure rate. Not only must intercourse be premeditated but also users may become sensitised to the rubber or spermicide. Users are more likely to carry Escherichia coli vaginally ${ }^{17}$ and to suffer recurrent urinary tract infectionsperhaps because of the pressure of the rim of the cap on the base of the bladder. ${ }^{18}$ This effect is less likely in obese women ${ }^{19}$ and can often be solved with a smaller or less rigid diaphragm.

Women who persist with diaphragms can thus enjoy high reliability with a lowered risk of genital infections, infertility, and cervical neoplasia. The diaphragm is still not, however, a good form of contraception for younger women, but continued developments should enable barrier contraception to become less premeditated and less messy and so less of a barrier to a fulfilling physical relationship.

\section{Peter Stott}

General Practitioner,

Tadworth,

Surrey KT20 5TA

Honorary Research Fellow,

Epidemiology and Health Care Research Unit,

Robens Institute,

University of Surrey

1 Bone M. The family planning services. London: HMSO, 1978

2 Cartwright A. How many children? London: Routledge and Kegan Paul; 1976.

3 Family Planning Information Service. Fact sheet C2. London: Family Planning Association, July 1984.

4 Stott PC. Contraceptive behaviour and fertility patterns in an inner London group practice. $\mathcal{F} R$ Coll Gen Pract 1980;30:340-6.

5 Davies GAM, Frankland JC. The first three months of free contraception in a market town group practice. $\mathcal{F} R$ Coll Gen Pract 1976;26:547-50.

6 Vessey $M$, Wiggins $P$. Use effectiveness of the diaphragm in a selected family planning clinic population in the UK. Contraception 1974;9:15-21.

7 Vessey M, Doll R, Peto R, et al. A long term follow up study of women using different methods of contraception: an interim report. J Biosoc Sci 1976;8:375-427.

8 Vessey M, Lawless M, Yeates D. Efficiency of different contraceptive methods. Lancet 1982;i:841-2.

9 Zapka JG, Pastides H, Rudenberg E. Diaphragm method contraceptors: implications for service organisation and delivery. Health Educ $Q$ 1985;12:245-57

10 Cramer DW, Goldman MB, Schiff I, et al. Contraceptive failures in the US. Estimates from the 1982 national survey of family growth. Fam Plann Perspect 1986;18:200-9.

11 Ansari AH, Gould KG. Contraception and the cervix. Advances in Contraception 1986;2:101-15.

12 Harrison HR, Costin M, Meder J, et al. Cervical chlamydia trachomatis infection in university women: relationship to history, contraception, ectopy and cervicitis. Am $\mathcal{f}$ Obstet Gynecol 1985;153:244-51.

13 Collins JA, Gillett PG, Perlin IA, et al. Microbiological and histological findings in the fallopian tubes of women using various contraceptive methods. Contraception 1984;30:457-66.

14 Cramer DW, Belisle S, Wilson E. The relationship of tubal infertility to barrier method and oral contraceptive use. FAMA 1987;257:2446-50.

15 Guillebaud J. Contraception: your questions answered. London: Pitman, 1982.

16 Hicks DR, Martin LS, Getchell JP, et al. Inactivation of HTLV III/LAV infected cultures of normal human lymphocytes by nonoxynol-9 in vitro. Lancet 1985;ii:1422-3.
17 Watts B, Goldacre MJ, Loudon N, Annat DJ, Harris RI, Vessey MP. Prevalence of E Coli in the vagina of normal young women. Br $\mathcal{Y}$ Obstet Gynaecol 1981;88:588-95.

18 Gillespie L. The diaphragm: an accomplice in recurrent urinary tract infections. Urology $1984 ; 24: 25-30$

19 Vessey MP, Metcalf MA, McPherson K, Yeates D. Urinary tract infection in relation to diaphragm use and obesity. Int $\mathcal{F}$ Epidemiol 1987;16:1-4.

\section{Games to play and accidents to prevent}

Britain has lagged behind many other countries in reducing pedestrian accidents, and 3090 children under 5 were killed or injured as pedestrians in $1986 .^{1}$ As was pointed out at a conference of the Parliamentary Advisory Council for Transport Safety and the Child Accident Prevention Trust, these accidents tend not to cluster round accident "black spots" and so cannot be much reduced by low cost engineering methods. Young children's perceptual and cognitive limitations make them unable to cope with traffic, ${ }^{2}$ and parents may expect too much of them, both in their attempts to teach road safety and in their failures of supervision. ${ }^{3}$ Responses to the need for better education on road safety have included books on the subject for children and their parents and preschool traffic clubs. ${ }^{24}$

The idea of teaching materials tailored to child development, for parents to use continuously, originated from Scandinavian preschool traffic clubs. ${ }^{2}$ In Norway, for instance, members had a $20 \%$ lower accident rate than nonmembers $(40 \%$ lower in Oslo), though the reduction may be explained, at least in part, by more safety consciousness among member families. ${ }^{5}$ In Britain the Transport and Road Research Laboratory has developed materials on the Scandinavian pattern, with five attractive books to be sent to the child every six months from the 3rd birthday. These tell parents what to teach when, with exercises and games that stimulate interest-things to do at home and in the street. ${ }^{4}$ Parental supervision and safe places to play are recurring themes. The books also have a general educational valueand they are fun (one child told me he could not wait for the next book). A controlled evaluation of the pilot book suggested favourable effects, with no social class variation. ${ }^{6}$ Since 1985 the London boroughs have run "Streetwise Kids," using the five books. It has 34000 members and there is much enthusiasm, although it is too soon to judge its effect on accidents.

Ever since 1984, according to answers to parliamentary questions, the government has been considering the possibilities of a national preschool road safety club and of private sector funding for it. At a recent meeting with the Minister for Roads and Traffic a firm decision was made to go ahead as soon as possible. The aim is a free membership club funded by some private organisation. One problem, however, is how to send every child a personal invitation to join. Streetwise Kids has been impeded by being unable to do this, and mothers from the lower social classes were significantly less likely than the others to have enrolled their children. Unlike Scandinavia, Britain has no easily accessible register of children and has less formalised preschool groups.

For the future computerised family practitioner committee lists or district health authority lists seem likely to provide the best basis. Arranging for them to be used for this purpose would pose some problems, but they should be soluble. The time for health authorities to consider how to do this is now, 
while the traffic club scheme is being planned. This venture must not become bogged down in protracted negotiations; for ultimately it could have a pervasive influence in reducing death and disability well beyond the age of 5 .

DAPHNE GLOAG

Staff editor, $B M \mathcal{F}$

1 Department of Transport. Road accidents Great Britain 1986. The casualty report. London: HMSO, 1987:103.

2 Downing CS. Improving parental road safety practice and education with respect to preschool children. In: Foot CH, Chapman AJ, Wade FM, eds. Road safety research and practice. children. In: Foot CH, Chapman

3 Sadler J. Children and road safety: a survey amongst mothers. London: HMSO, 1972. (Government Social Survey report.)

4 Transport and Road Research Laboratory. My traffic book: 1-5. London: London Residuary Body, 1985-7. (Adapted for "Streetwise Kids" from TRRL material; bbtainable from London Acciden Analysis Unit, London Research Centre, County Hall, London SE1 7PB.)

5 Schioldborg P. Children, traffic and traffic training. An analysis of the "Children's Traffic Club." University of Oslo: Psychological Institute, 1974. (English translation from TRRL.)

6 Downing CS, Murray G, Durow C. Trials of a road safety booklet for a pre-school traffic club. Crowthorne: Transport and Road Research Laboratory, 1981. (TRRL laboratory report 992.)

\section{Antidepressants and skin disease}

Many patients with chronic skin problems have depression, which may often be unrecognised, and some will improve when treated with antidepressants. Itch and sleep disturbance, for instance, are common in those with chronic skin conditions and may be helped by antidepressants, particularly trimipramine. Recently, however, it has become apparent that antidepressants may help in some skin conditions even when the patient is not depressed. ${ }^{1}$ They have been used with some success to treat chronic urticaria, angioedema and dermatographism, idiopathic cold urticaria, nocturnal pruritus in atopic eczema, postherpetic neuralgia, and the pain of diabetic neuropathy. ${ }^{1}$

Imipramine was discovered in the search for antihistamines, as was chlorpromazine. Tricyclic antidepressants, benzodiazepines, and phenothiazines are closely relatedlike car keys with small variations. How they work is still not clear, but they inhibit uptake of noradrenaline and so potentiate sympathetic activity. They can reduce skin blood flow, lower skin temperature, and reduce sweating. They also are sedatives, antiemetics, muscle relaxants, and local anaesthetics.

So far as the individual drugs are concerned patients with chronic urticaria and dermatographism may benefit particularly from doxepin ${ }^{2 \cdot 5}$; those with postherpetic neuralgia from pimozide and trimipramine ${ }^{6}$; and those with chronic aphthous ulcers from phenelzine. ${ }^{7}$ Emotional factors are important in these conditions. Amitryptiline has relieved unilateral itch after strokes, ${ }^{8}$ and naloxone helps the pruritus of cholestatic jaundice, illustrating that endorphins may have a central modulating effect on itch. ${ }^{9}$

Epiphenomena are part of all chronic illnesses, and when they are not readily explained they are often assumed to have psychological origins. Sometimes this is true, but doctors may overestimate the number of problems that have psychological origins. ${ }^{10}$ Nevertheless, antidepressants may often be indicated in patients with skin problems. They may also be indicated for patients whose problems are purely dermato- logical, particularly for the urticarias, pruritus, and other pain related syndromes. ${ }^{1}$

Antidepressants do, however, have many side effects, and they may interact with other drugs. They should not therefore be used as a substitute for thought and proper evaluation, especially when "waiting and seeing" is an option.

P C H NEWBOLD

Consultant Dermatologist,

Worcester Royal Infirmary,

Worcester WR1 3AS

1 Gupta MA, Gupta AK, Ellis CN. Antidepressant drugs in dermatology: an update. Arch Dermatol 1987;123:647-52.

2 Richelson E. Tricyclic antidepressants and histamine H1 receptors. Mayo Clin Proc 1979;54: 669-74.

3 Sullivan TJ. Pharmacological modulation of the whealing response to histamine in normal skin: identification of doxepin as a potent in vivo inhibitor. F Allergy Clin Immunol 1982;69:260-7. 4 Guin JD. Treatment of urticaria. Med Clin North Am 1982;66:831-49.

5 Monroe EW. Chronic urticaria- a review of drug management. In: Champion RH, Greaves MW, Black AK, Pye RJ, eds. The urticarias. Edinburgh: Churchill Livingstone, 1985:205-11.

6 Duke EE. Clinical experience with pimozide: emphasis on its use in post-herpetic neuralgia. 7 Am Acad Dermatol 1983;8:845-50.

7 Rosenthal S. Does phenezine relieve aphthous ulcers of the mouth? N Englf Med 1982;311:1442. 8 Massey EW. Unilateral neurogenic pruritus following stroke. Stroke 1984;15:901-3.

9 Greaves MW. The nature and management of pruritus. Practitioner 1982;226:1223-5.

10 Baughman RD, Sobel R. Emotional factors in psoriasis. In: Farber EM, Cox AJ, eds. Psoriasis; proceedings of 2nd international symposium. New York: Yorke Medical Books, 1977:180-8.

\section{Drug regulation: evolution or revolution?}

The history of drug regulation in Britain has been one of evolution. ${ }^{1}$ From the Arsenic Act of 1851 to the Medicines Act of 1968 each legislative step has been prompted by parliamentary, professional, or public concern over particular aspects of the manufacture, promotion, prescription, or sale of medicines. The Medicines Act, stimulated by the thalidomide disaster, created the licensing authority (represented for human medicines by the health ministers) with powers to grant (or revoke) product licences for the sale or supply of medicines and made it an offence to market a drug without such a licence. In discharging its responsibilities the authority obtains advice from committees established under the act, of which the Committee on Safety of Medicines is the most widely known. Although the Committee on Safety of Medicines is only advisory, the licensing authority has rejected its views only very rarely. The committee is thus extremely influential in deciding which drugs should be available on the market.

Recently radical proposals have been put forward by $\mathrm{Dr}$ David Green, director of the Institute of Economic Affairs' health unit, who believes that the British licensing system has failed. ${ }^{2} \mathrm{He}$ claims that current regulatory requirements impose important additional costs and delays in drug development; preclinical toxicity studies have not proved a wholly reliable indication of safety in man; the licensing system fails to take enough account of the true nature of the risks and benefits of new medicines; and as a result some drugs that might have been effective have been rejected while others have been approved and later found to be toxic.

Green therefore suggests that our licensing procedure should be abandoned and replaced by systems whereby the decision whether a drug should be marketed would rest 